\title{
COMPARATIVE STUDY BETWEEN PATCHING AND CONSERVATIVE TREATMENT OF TRAUMATIC TYMPANIC MEMBRANE PERFORATION
}

\author{
By \\ Mohamed Abd El-Azez El-Daba, Ahmed Mohamed Abd El-Fatah, and \\ Ahmed Mostafa Ahmed Abo Mansora
}

Otorhinolaryngology Department, Faculty of Medicine, Al-Azhar University

E-Mail: ahmedmostafaabomansora@gmail.com

\begin{abstract}
Background: Trauma remains a regular occurrence relating to activities and lifestyle of humans and it can affect any part of the body. The ear is located within the cranio-facial skeleton which is exposed to environmental trauma that can occur as blunt injuries like contusion, concussion, decompression, and penetrating injuries as fractures.

Objective: The aim of the present work was to investigate the effect of patching of traumatic TMP either with gel foam or steri-strips, and to compare it with conservative treatment depending on closure rate, closure time, hearing gain, and rate of otorrhoea.

Patients and Methods: This prospective study was carried out on sixty patients who attended to outpatient clinic of Al-Hussien and Sayed Galal Hospitals, Al-Azhar University from February 2019 to December 2019. All patients who came with traumatic tympanic membrane perforation were screened. They were divided randomly into three equal groups; group A was treated conservatively, group B was treated by steri-strip patch, and group $\mathrm{C}$ was treated by gel foam patch.
\end{abstract}

Results: The closure rates of the perforations in conservative group, Steri-Strips patching and gel foam patching groups were $80 \%, 95 \%$, and $100 \%$, respectively. There was no statistically significant difference in tympanic membrane closure rate between the 3 groups. Steri-Strip and gel foam patching groups showed shorter healing times compared with the conservative group. However, there was an increased rate of otorrhea in the Steri-Strip group and conservative group compared with gel foam patching group.

Conclusion: Steri-strip and gel foam patching accelerated the closure of small, moderate and large traumatic tympanic membrane perforations, closure rates and closure times did not differ significantly among the steristrip and gel foam groups. The closure time increased in steri-strip and gel foam groups in comparison to conservative group and this difference is highly significant.

Keywords: conservative, patching, Traumatic tympanic membrane perforation.

\section{INTRODUCTION}

Major injuries affecting the ears can lead to disturbances in hearing and difficulties in maintenance of balance especially when the inner ear is affected (Eagles et al., 2013). Treatment of TTMP range from inactive watchful waiting, active intervention to surgical intervention (Jellinge et al., 2015). Otolaryngologists have however been advised to be reluctant in offering surgical intervention in cases of TTMP without significant symptoms as most patients will heal spontaneously within two months (Smith et al., 2012). 
Active interventions include topical application of substances like epidermal growth factor, enoxaparin, and ascorbic acid to stimulate epithelization for quick closure or to prevent formation of sclerotic plaques in the perforated membrane (Lou et al., 2016).

Surgical intervention is indicated in cases of complications like perilymph fistula, facial paralysis, severe vertigo, or profound sensorineural hearing loss. Such diagnosis should be made early and treatment offered promptly (Smith et al., 2012).

It included exploration and tympanoplasties, closure of the perforation with stents in the form of simple patches or as patches laden with substances in the form of silk fibroin membranes or steri-strips patching (Park et al., 2011)

The aim of the present work was to investigate the effect of patching of traumatic TMP either with gel foam or steri strips and to compare it with conservative treatment depending on closure rate, closure time, hearing gain, and rate of otorrhoea.

\section{PATIENTS AND METHODS}

This prospective study was carried out on sixty patients who attended to outpatient clinic of Al-Hussien and Sayed Galal University Hospitals from February 2019 to December 2019. All patients who came with traumatic tympanic membrane perforation were screened. They were divided randomly into three equal groups; group A was treated conservatively, group B was treated by steri-strip patch and group $\mathrm{C}$ was treated by gelfoam patch. All patients signed informed consents before the study.

Exclusion criteria: Otitis media, granulation tissue in the ear, persistent otorrhea, severe vertigo, profound hearing Loss, facial palsy and temporal bone fracture.

All patients were submitted to full history, general and ENT examinations. Pure tone audiometry is performed. In observation group, there was no intervention, but the patients underwent medical treatment including systemic antibiotics, nasal decongestant and analgesics then regular follow-up.

Transcanal approach was under local anesthesia. Under the otomicroscope, the external auditory canal was injected with $2 \%$ lidocaine and 1:100,000 epinephrine at the bony cartilaginous junction. A small piece of a Steri-Strips was trimmed to provide a 1- or 2-mm overlapping margin around the perimeter of the perforation. Gel foam a highly absorbent, non-elastic sponge manufactured from neutral gelatine of pharmaceutical grade material around $4 \mathrm{~mm}$ thick was used in group C. Minimal amount of gel foam of appropriate size and shape was applied over the perforation and held firmly in place. No ear drops or packing of the auditory canal were used in either group.

\section{Statistical analysis:}

Recorded data were analyzed using the statistical package for social sciences, version 20.0 (SPSS Inc., Chicago, Illinois, USA). Quantitative data were expressed as mean \pm standard deviation (SD). Qualitative data were expressed as frequency and percentage. 
The following tests were done:

- Chi-square (x2) test of significance was used in order to compare proportions between qualitative parameters.

- A one-way analysis of variance (ANOVA) when comparing between more than two means.

- Post Hoc test: Least Significant Difference (LSD) was used for multiple comparisons between different variables.
- The confidence interval was set to $95 \%$ and the margin of error accepted was set to $5 \%$. So, the p-value was considered significant as the following:

- P-value <0.05 was considered significant.

\section{RESULTS}

No statistically significant difference between both groups according to demographic data (Table 1).

Table (1): Comparison between three groups according to demographic data

\begin{tabular}{|c|c|c|c|c|}
\hline Demographic & $\begin{array}{c}\text { Conservative } \\
\quad(\mathbf{n}=\mathbf{2 0})\end{array}$ & $\begin{array}{c}\text { Steri-strip } \\
\quad(\mathbf{n}=\mathbf{2 0})\end{array}$ & $\begin{array}{c}\text { Gel foam } \\
(\mathbf{n}=\mathbf{2 0})\end{array}$ & p-value \\
\hline \multicolumn{5}{|l|}{ Age (years) } \\
\hline Range & $15-59$ & $17-59$ & 16-59 & \multirow{2}{*}{$>0.05$} \\
\hline Mean \pm SD & $29.97 \pm 5.69$ & $28.77 \pm 5.46$ & $29.37 \pm 6.07$ & \\
\hline \multicolumn{5}{|l|}{ Sex } \\
\hline Male & $9(45 \%)$ & $8(40 \%)$ & $10(50 \%)$ & \multirow{2}{*}{$>0.05$} \\
\hline Female & $11(55 \%)$ & $12(60 \%)$ & $10(50 \%)$ & \\
\hline \multicolumn{5}{|l|}{ Laterality } \\
\hline Right & $6(30 \%)$ & $8(40 \%)$ & $7(35 \%)$ & \multirow{2}{*}{$>0.05$} \\
\hline Left & $14(70 \%)$ & $12(60 \%)$ & $13(65 \%)$ & \\
\hline
\end{tabular}

F-One Way Analysis of variance; \#x2: Chi-square test

No statistically significant difference between groups according to etiology (Table 2).

Table (2): Comparison between three groups according to etiology

\begin{tabular}{|l|c|c|c|c|}
\hline Etiology & $\begin{array}{c}\text { Conservative } \\
(\mathbf{n = 2 0})\end{array}$ & $\begin{array}{c}\text { Steri-strip } \\
(\mathbf{n = 2 0})\end{array}$ & $\begin{array}{c}\text { Gel foam } \\
(\mathbf{n = 2 0})\end{array}$ & $\begin{array}{c}\text { p- } \\
\text { value }\end{array}$ \\
\hline Slap injury & $9(45 \%)$ & $11(55 \%)$ & $8(40 \%)$ & \\
\cline { 1 - 4 } Self cleaning & $6(30 \%)$ & $5(25 \%)$ & $7(35 \%)$ & \multirow{2}{*}{$>0.05$} \\
\cline { 1 - 4 } RTA/ Fall & $2(10 \%)$ & $1(5 \%)$ & $2(10 \%)$ & \\
\cline { 1 - 3 } Blow & $1(5 \%)$ & $1(5 \%)$ & $1(5 \%)$ & \\
Iatrogenic & $2(10 \%)$ & $2(10 \%)$ & $2(10 \%)$ & \\
\hline
\end{tabular}

$\mathrm{x} 2$ : Chi-square test; 
No statistically significant difference between groups according to healing outcome of traumatic TM perforations (Table 3).

Table (3): Comparison between three groups according to healing outcome traumatic TM perforations

\begin{tabular}{|l|c|c|c|}
\hline $\begin{array}{l}\text { Healing outcome of } \\
\text { traumatic TM perforations }\end{array}$ & $\begin{array}{c}\text { Conservative } \\
(\mathbf{n = 2 0})\end{array}$ & $\begin{array}{c}\text { Steri- } \\
\text { strip } \\
(\mathbf{n = 2 0})\end{array}$ & $\begin{array}{c}\text { Gel } \\
\text { foam } \\
(\mathbf{n = 2 0})\end{array}$ \\
\hline Small & $\mathbf{5}$ & $\mathbf{6}$ & $\mathbf{5}$ \\
\hline Healing & & & \\
\hline No. & 5 & 6 & 5 \\
\hline$\%$ & $100.0 \%$ & $100.0 \%$ & $100.0 \%$ \\
\hline Medium & $\mathbf{1 1}$ & $\mathbf{1 0}$ & $\mathbf{1 2}$ \\
\hline Healing & 9 & & \\
\hline No. & $81.8 \%$ & $100.0 \%$ & $100.0 \%$ \\
\hline$\%$ & $\mathbf{4}$ & $\mathbf{4}$ & $\mathbf{3}$ \\
\hline Large & & & \\
\hline Healing & 2 & 3 & 3 \\
\hline No. & $50.0 \%$ & $75.0 \%$ & $100.0 \%$ \\
\hline$\%$ & & $>0.05$ & \\
\hline p-value & \multicolumn{2}{|l}{} \\
\hline
\end{tabular}

$\mathrm{x} 2$ : Chi-square test;

No statistically significant difference between groups according to occurrence of infection and No. of patients with

healed TM perforation after control of infection. (Table 4).

Table (4): Comparison between three groups according to occurrence of infection and numbers of patients with healed TM perforation after control of infection

\begin{tabular}{|c|c|c|c|c|}
\hline Parameters Groups & $\begin{array}{c}\text { Conservative } \\
(\mathbf{n}=\mathbf{2 0})\end{array}$ & $\begin{array}{l}\text { Steri- } \\
\text { strip } \\
(\mathbf{n}=\mathbf{2 0})\end{array}$ & $\begin{array}{c}\text { Gel } \\
\text { foam } \\
(\mathbf{n}=\mathbf{2 0})\end{array}$ & $\begin{array}{l}\text { p- } \\
\text { value }\end{array}$ \\
\hline Occurrence of infection & $2(10 \%)$ & $5(25 \%)$ & $1(5 \%)$ & \\
\hline $\begin{array}{l}\text { No. of patients with } \\
\text { healed TM perforation } \\
\text { after control of infection }\end{array}$ & $0(0 \%)$ & $4(80 \%)$ & $\begin{array}{c}1 \\
(100 \%)\end{array}$ & $>0.05$ \\
\hline
\end{tabular}

$\mathrm{x} 2$ : Chi-square test;

Higher closure rates in steri-strip and gel foam groups compared to conservative group, but insignificant statistically significant difference present between groups according to closure times. No statistically significant difference between groups according to hearing gain $(\mathrm{dB})$ statistically significant higher of otorrhea in steri-strip compared to conservative and gel foam groups (Table 5). 
COMPARATIVE STUDY BETWEEN PATCHING AND CONSERVATIVE... 383

Table (5): Comparison between three groups according to outcome of closure rates, closure time, hearing gain and rate of otorrhea

\begin{tabular}{|c|c|c|c|c|}
\hline $\mathrm{P}_{\text {Parameters }}$ Groups & $\begin{array}{c}\text { Conservative } \\
\quad(\mathbf{n}=\mathbf{2 0})\end{array}$ & $\begin{array}{l}\text { Steri-strip } \\
\quad(\mathbf{n}=\mathbf{2 0})\end{array}$ & $\begin{array}{c}\text { Gel foam } \\
(n=20)\end{array}$ & $\begin{array}{c}\text { p- } \\
\text { value }\end{array}$ \\
\hline \multicolumn{5}{|l|}{ Closure rates, $(\%)$} \\
\hline Yes & $16(80 \%)$ & $19(95 \%)$ & $20(100 \%)$ & \multirow{2}{*}{0.058} \\
\hline No & $4(20 \%)$ & $1(5 \%)$ & $0(0 \%)$ & \\
\hline \multicolumn{5}{|l|}{ Closure time (days) } \\
\hline Mean \pm SD & $32.96 \pm 7.09$ & $25.37 \pm 7.44 \mathrm{a}$ & $23.89 \pm 8.51 \mathrm{a}$ & $0.011 *$ \\
\hline \multicolumn{5}{|l|}{ Hearing gain, (Db) } \\
\hline Mean \pm SD & $13.18 \pm 2.78$ & $13.91 \pm 2.78$ & $14.03 \pm 2.68$ & $>0.05$ \\
\hline Otorrhea, ( \%) & $2(10 \%)$ & $5(25 \%)$ & $1(5 \%)$ & $>0.05$ \\
\hline
\end{tabular}

x2: Chi-square test;

\section{DISCUSSION}

Tympanic membrane perforations may occur as the result of a pressure wave in the external ear canal, or by direct penetration. About 50\% are attributable to slap injuries or direct blows (Lou et al., 2012).

An overview on traumatic TM perforations reported most common complaint was tinnitus followed by aural fullness and reduced hearing (Wani et al., 2016).

In our study, the most common symptom was hearing loss followed by pain and ear buzzing. The most distressing symptom was ear buzzing.

Previous studies have noted higher prevalence of traumatic TM perforation in female population consistent with our findings (Lou et al., 2012).

Traumatic perforations of the tympanic membrane have a very high chance of spontaneous healing. So, early surgical intervention of traumatic perforations is not indicated by few studies (Al-Juboori, 2014).
In our study, the healing outcome with conservative management was very good. However, ear buzzing still present for initial few weeks till the perforation reduced or healed. Though two of them developed a secondary infection later on; their healing outcome was $100 \%$. They were treated by simple dry ear mopping and the infection was controlled. Presence of infection did not affect the healing process.

In this study, Steri-Strips patching showed a relatively increased rate of otorrhea. No difference has been found between Steri-Strips and sutures or tissue adhesives in terms of infection in closure of surgical incisions (Coulthard et al., 2010).

In this study, the TMP closed in 4 of 5 Steri-Strips patching patients after otorrhea stopped. This may have occurred as a result of angiogenesis induced by infection. In this study, closure rates and closure times in patients with otorrhea were not different from closure rates and closure times in patients without otorrhea.

Gel foam is highly purified neutral gelatin of pharmaceutical grade material. 
It is non-toxic, non-allergic, nonimmunogenic and non-pyrogenic. It is usually absorbed completely in 4-6 weeks without inducing excess scar tissue. In a recent study it was also concluded that gel foam patching helps epithelial migration, promotes edema, granulation tissue formation at the edges and aids in ear drum healing (Huang et al., 2017).

In this prospective study, we compared the healing of TM perforations in steristrip, gel foam groups and conservative group. We found that the overall healing rate differed insignificantly between the three groups at different time points. The application of steri-strip and gel foam patches promoted the healing of TM perforations.

\section{CONCLUSION}

The findings of this study revealed that steri-strip and gel foam patching accelerated the closure of small, moderate and large traumatic tympanic membrane perforations, and that closure rates and closure times did not differ significantly among the steri-strip and gel foam groups. The closure time showed highly significant difference between conservative group, steri-strip and gel foam groups. Hearing gain and rate of otorrhea were not statistically significant among three groups, but possibility of otorrhea occurring when using Steri-Strips patching.

\section{REFERENCES}

1. Al-Juboori AN. (2014): Evaluation of Spontaneous Healing of Traumatic Tympanic Membrane Perforation. Gen Med., 2:129-134.

2. Coulthard P, Esposito $M$ and Worthington HV. (2010): Tissue adhesives for closure of surgical incisions. Cochrane Database Syst Rev. 5:CD004287-50.
3. Eagles K, Fralich $L$ and Stevenson JH. (2013): Ear trauma. Clin Sports Med., 32:303-316.

4. Guenzani S, Mereu D, Messersmith M, Olivari D, Arena $M$ and Spanò A. (2016): Inner-ear decompression sickness in nine trimix recreational divers. Diving Hyperb Med., 46:111-116.

5. Huang $P$, Zhang $S$, Gong $X$, Wang $X$ and Lou ZH. (2017): Endoscopic observation of different repair patterns in human traumatic tympanic membrane perforations. Braz J Otorhinolaryngol., $\quad$ pii: $\quad$ S18088694(17):30111-8.

6. Jellinge ME, Kristensen $S$ and Larsen $K$. (2015): Spontaneous closure of traumatic tympanic membrane perforations: observational study. J Laryngol Otol., 129:950-954.

7. Lou ZC, Lou ZH. And Zhang QP. (2012): Traumatic tympanic membrane perforations: a study of etiology and factors affecting outcome.Am J Otolaryngol., 33:549-55.

8. Lou Z, Yang J, Tang Y and Fu Y. (2016): Topical application of epidermal growth factor with no scaffold material on the healing of human traumatic tympanic membrane perforations. Clin Otolaryngol., 9:284-5.

9. Park MK, Kim KH, Lee JD and Lee BD. (2011): Repair of large traumatic tympanic membrane perforation with a Steri-Strips patch. Otolaryngol Head and Neck Surg., 145:581-5.

10. Smith M, Darrat I and Seidman M. (2012): Otologic complications of cotton swab use: one institution's experience. Laryngoscope, 122:409-411.

11. Wani A, Rehman A, Lateef $S$, Malik R, Ahmed A, Ahmad W. (2016): Traumatic tympanic membrane perforation: An overview. Indian J Otol., 22:100-112. 
COMPARATIVE STUDY BETWEEN PATCHING AND CONSERVATIVE... 385

در اسة مقارنة بين ترقبع و علاج ثقب غشاء طبلة الأذن الرضحي

محمد عبد العزيز الضبع، أحمد محمد عبد الفتاح، أحمد مصطفى أحمد أبومنصوره قسم الأذن والأنف والحنجرة، كلية طب الأزهر

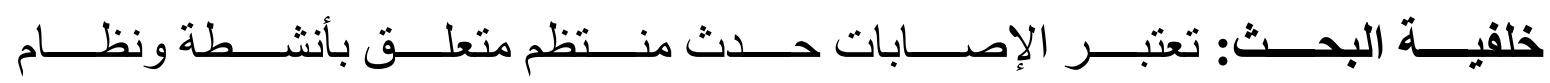

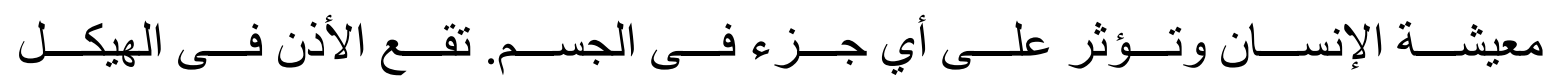

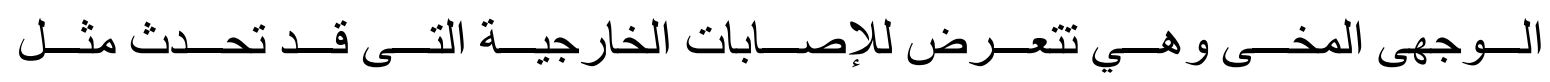

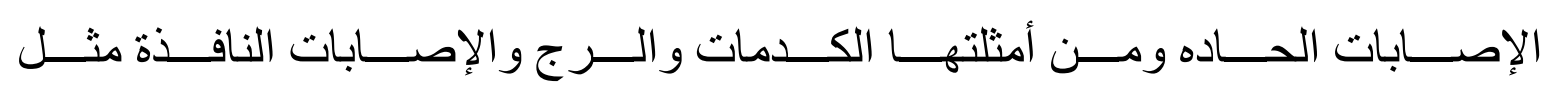
الكسور

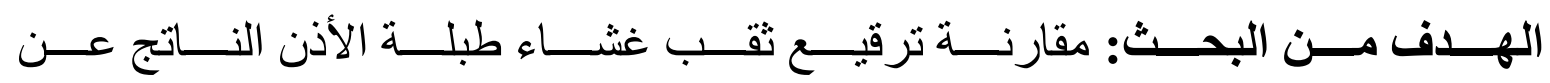

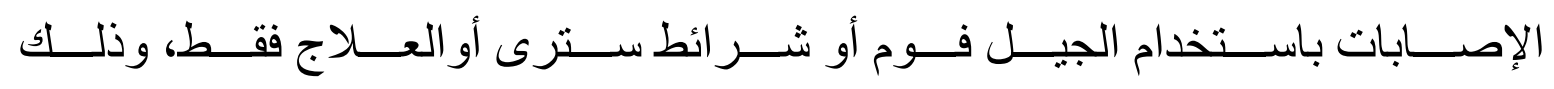

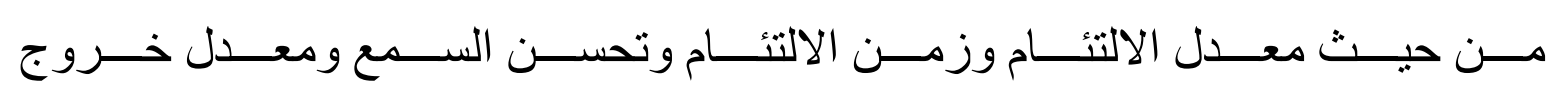

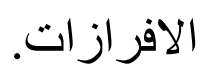

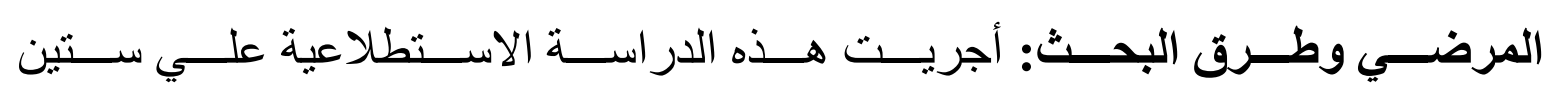

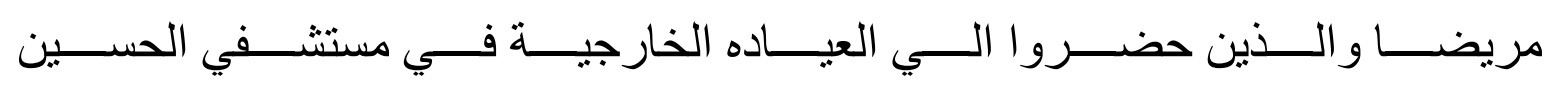

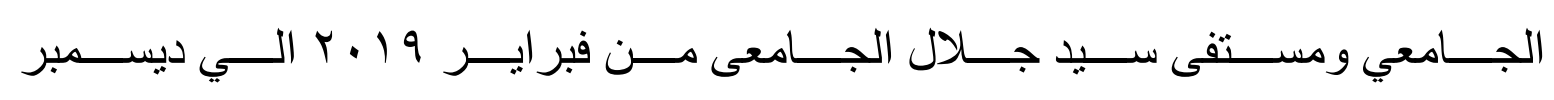

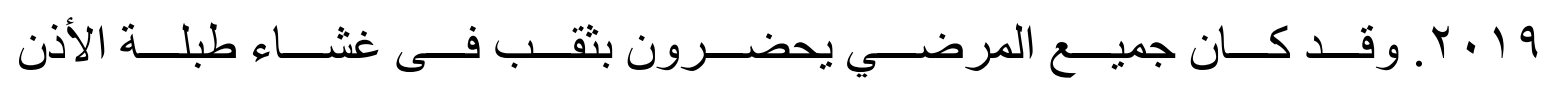

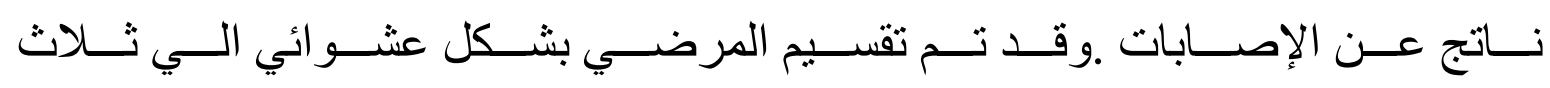

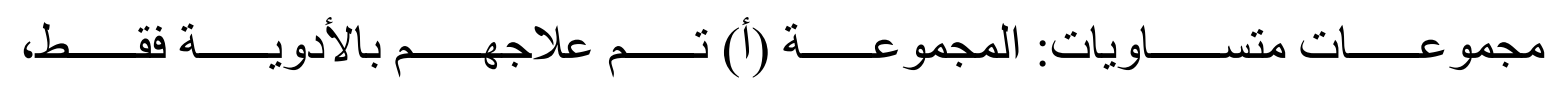

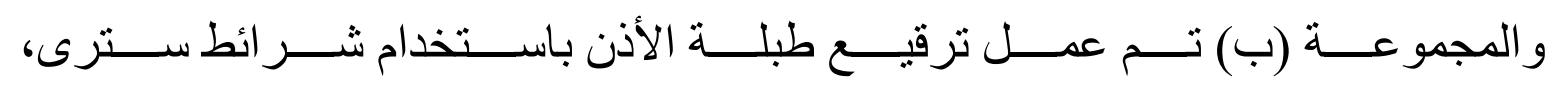
و المجمو عه (ج) تم عملية ترقيع طبلة الأذن باستخدام الجيل فوم.

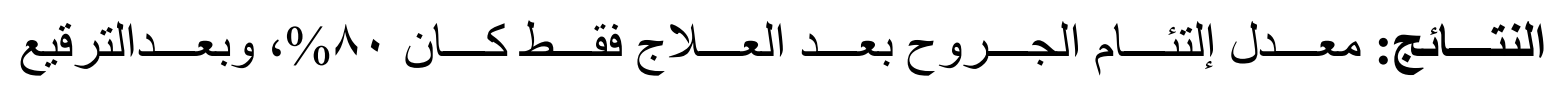

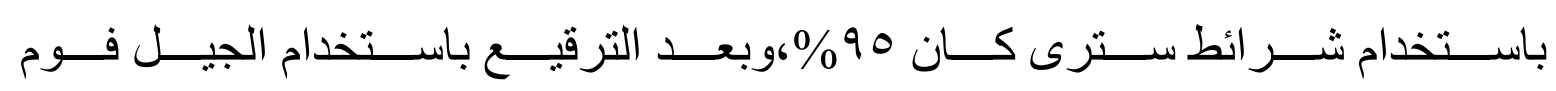




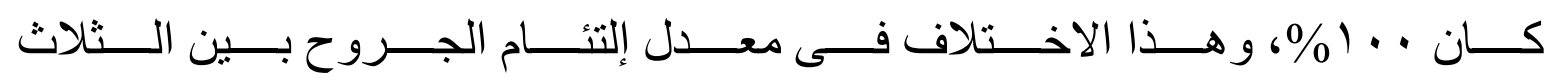

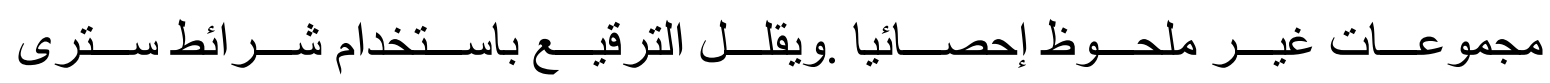

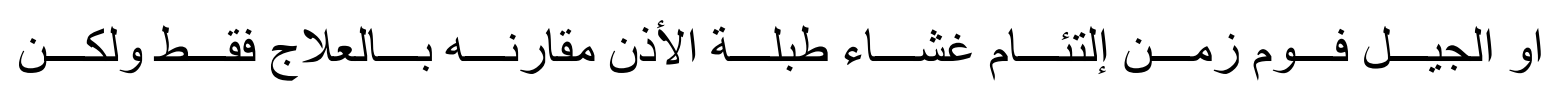

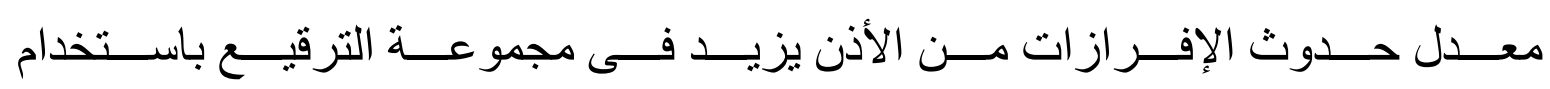

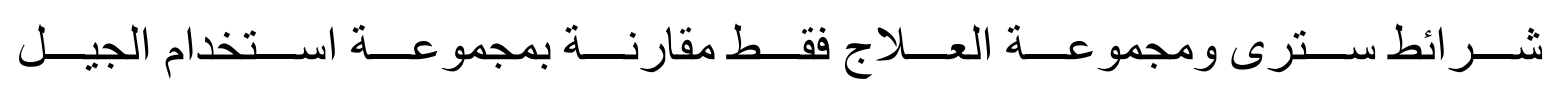
فوم.

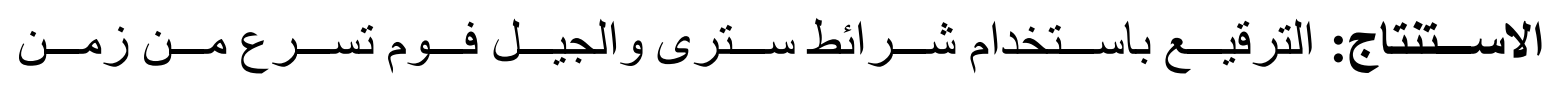

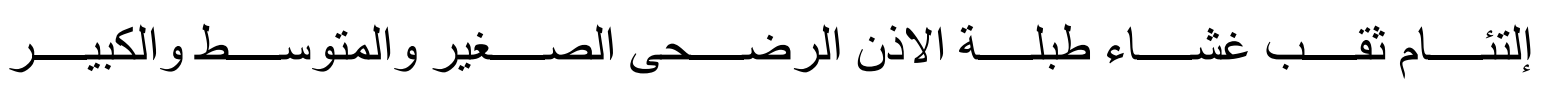

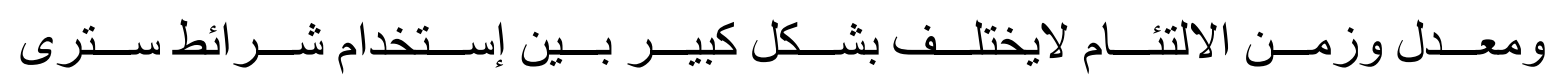

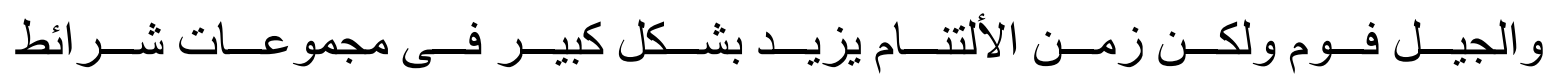
سنرى و الجيل فوم مقارنة بالعلاج فقط. 